\title{
Analysis of Bakery Production Units Using Quality Function Deployment (QFD) Method
}

\author{
Yatti Sugiarti, Shinta Maharani, Widia Putri Ayudia, Ana \\ Agroindustry Technology Education Study Program \\ Universitas Pendidikan Indonesia \\ Bandung, Indonesia \\ attisugiarti5@upi.edu
}

\begin{abstract}
Bakery's production unit is a business activity that is implement by the competency of Agricultural Processing Technology expertise in SMK Negeri 2 Cilaku Cianjur to develop the student's competence work in the field of bakery. The performance of production units improvement, need to be prioritized in order to improve the suitability of the curriculum of Vocational Competency Expertise SMK Negeri 2 Cilaku Cianjur with competency needs of the agriculture industry. Quality Function Deployment (QFD) is a method that measured from a very specific customer needs to process then assured customer necessity could be covered. Analysis using QFD method could provide an overview of the needs of consumers (industry). Further, this data will support the program study to improve the effort regarding to quality improvement efforts to be undertaken bakery's production unit so the creation of relevance. This study, moreover, aims (1) to find out to what extent the application of QFD method in UP bakery SMK Negeri 2 Cilaku Cianjur and (2) to find out what are the engineering interests priority that must be developed by the bakery's production unit so that it could develop the competence of students work to fit the needs of industrial doughnuts. Study on the extent of application of the QFD method on activities implemented through the bakery's production unit the interview with a teacher Supervisor bakery's production unit, QFD method could be said to have been applied if it has been carrying out the stages of the application of QFD, namely quality assurance products and services, the assessment of the costumer against products and services, making the costumer need, costumer surveys, drafting checklists as well as making the matrix House of Quality (HOQ). In addition, the analysis method using QFD is also conducted in order to find the effort on quality improvement techniques that should be developed by bakery's production unit SMK Negeri 2 Cianjur Cilaku. The effort stated based on the needs of industrial employment competence of doughnuts. The results of this study suggest that (1) bakery's production unit has implemented a $57.14 \%$ stages of QFD method or there is four of the seven stages of QFD methods have been applied, and (2) the priority interests of techniques should be developed by the bakery's production unit in order to develop the employment competence of students in accordance with the needs of industry learning is doughnuts productive subjects and increased oversight.
\end{abstract}

Keywords-bakery's production unit, competence of students work, Quality Function Deployment, the priority interest of techniques

\section{INTRODUCTION}

Education is one area of activity that plays a strategic role in efforts to improve the quality of human resources (HR).
Through education aims to equipped with various competencies to become skilled human resources and could compete with other workers. One level of education in Indonesia is vocational secondary education. Based on Law Number 20 Year 2003 on National Education System article 15 , vocational education is a secondary education that prepares students primarily to work in a particular field [1].

SMK Negeri 2 Cilaku Cianjur is one of vocational secondary education that prepares its students to work in certain fields. Not only classroom's activities, but also implement the program Production Unit (UP). Compliance of SMK curriculum Package Expertise of Agricultural Processing Technology (TPHP) SMK Negeri 2 Cilaku Cianjur with the competence of agriculture industry needs could be improved, one of them by prioritizing the improvement of production unit performance/ entrepreneurship [2].

Bakery production unit is one of the productive activities in the program practices of TPHP in SMK Negeri 2 Cianjur Cilaku to make bakery products (donuts). Each student gets an activity picket schedule at UP bakery with a series of preproduction preparation activities, donut production, marketing activities and cost analysis. Through this activity, students of TPHP skills competency SMK Negeri 2 Cilaku Cianjur competence could use UP as one of the learning media in improving the work function. The learning of the UP and Service is effective as a business-based learning program and as one of the teaching method to provide additional skills of students, in addition to increasing the achievement of the program of environment and match with the work/ industry [3]. Primarily, the production unit is a school quality improvement program designed as a forum to create entrepreneurial graduates and the improvement of skills and skills of human resources (students and teachers) [4].

Competence of work required by industry could be known by conducting analysis using Quality Function Deployment (QFD) method. This method could provide an overview of consumer (industry) needs for job competence and an illustration of the efforts that must be implemented by the school so that the creation of relevancy (conformity). QFD is a practice towards process improvement that could enable the business unit/ unit of production to exceed consumer expectations. QFD enables business units to select consumer-prioritized needs, find consumers' responses that develop the need and improve production processes to achieve maximum and effective production activities [5]. 
Analysis using QFD method embodied with House of Quality (HOQ) that aims to find the requirement of work competence according to consumer requirement (donut industry). In addition, with the discovery of the work competence needs of the donut industries, it could be improved quality UP Bakery so that there is a match between UP Bakery activities with work competence developed. Based on the previous explanation, this research aims to identify how to implement QFD method and how to improve the quality of bakery UP implemented by TPHP Skill Competency SMK Negeri 2 Cilaku Cianjur. Even more, so as to develop work competence in accordance with the needs of the donut industry by using QFD method embodied by making House of Quality (HOQ).

\section{METHOD}

The research conducted in bakery production unit in SMK Negeri 2 Cianjur, Addressed at Perintis Kemerdekaan Road, Village of Sirnagalih, Cilaku, Cianjur. The questionnaire activities spread to Maple Bakery Cianjur, PT. Agronesia BMC Bandung, and Anyelir Bakery Purwakarta. The benchmarking activities carried out in SMK Negeri Cikalongkulon, Cianjur and SMK Negeri 1 Bojongpicung, Cianjur. The study conducted in April 2017. This study is a case study with descriptive approach to examine the QFD method implementation and analysis using QFD method to find the competence requirement of donut industry and quality improvement as efforts that must be implement at UP bakery SMK Negeri 2 Cilaku Cianjur. The result illustrated in House of Quality (HOQ) matrix.

The participants of this research are (1) internship students at Maple Bakery and Anyelir Bakery each 2 and 4 person respectively. (2) The mentor of Bakery UP in SMK Negeri 2 Cilaku Cianjur. (3) The mentor in each industries; (4) supervisor of internship program in PT Agronesia BMC Division of Food and Beverage. (5) supervisor of internship program in Anyelir Bakery Purwakarta; (6) Advisory Teachers of Donuts Production Unit of SMK Negeri Cikalongkulon Cianjur; and (7) Advisory Teachers of Donuts Production Unit of SMK Negeri 1 Bojongpicung Cianjur. Data collection techniques involve interviews and questionnaires. The instruments used in this study are the guidelines for interviewing the application of QFD, work competence of industry needs, interview technical response guidance and relationship, benchmarking interview too and costumer need questionnaire. Validation of instruments performed by experts in the field of education who are Lecturer of Agro-Industry Technology Education related to work competence in industry.

\section{RESULT AND DISCUSSION}

\section{A. Application of QFD Method on Bakery PU SMK Negeri 2 Cilaku Cianjur}

UP bakery in SMK Negeri 2 Cilaku Cianjur has been applied the principle of TQM (Total Quality Management) in accordance with PU Management Guide as a Learning Resource of Students and Education Funding School in 2007. The principle of TQM is prioritizing the guarantee of quality products/ services to fit with consumer needs. UP bakery has applied $57.14 \%$ stages of QFD method or there are four from seven stages has been establish. The steps has been implemented are shown in the following table.
TABLE I. STAGE OF APPLICATION OF QFD

\begin{tabular}{|c|l|c|}
\hline No & \multicolumn{1}{|c|}{ Stages of Application of QFD } & $\begin{array}{c}\text { Description of the } \\
\text { Implementation }\end{array}$ \\
\hline 1 & $\begin{array}{l}\text { Guarantee the quality of products } \\
\text { and services }\end{array}$ & It's done \\
\hline 2 & Consumer ratings & It's done \\
\hline 3 & $\begin{array}{l}\text { Questionnaire consumer } \\
\text { assessment }\end{array}$ & It's done \\
\hline 4 & Consumer surveys & Not done yet \\
\hline 5 & Consumer needs & It's done \\
\hline 6 & Checklist of consumer needs & Not done yet \\
\hline 7 & Making House of Quality & \\
\hline
\end{tabular}

\section{B. Priority of Engineering Interest on Bakery Production} Unit SMK Negeri 2 Cilaku Cianjur

\section{1) Consumer Need Matrix}

There are 94 work competencies required by donut industry which are grouped into 8 groups. The competences are sanitation implementation, hygiene implementation, application of $\mathrm{K} 3$, knowledge and use of raw materials, knowledge and use of tools, application of work procedures, application of entrepreneurship concept, and work attitude.

\section{2) Planning Matrix}

\section{a) Consumer Satisfaction Performance}

The level of customer satisfaction is how much consumers feel satisfied (the needs are met) to the competence of students at the time of implementation internship in industry. The value of the level of customer satisfaction is determined by calculating the average value of the level of customer satisfaction. There are $17.12 \%$ of the average consumer satisfaction level of $2.33-2.67$ and there are $82.88 \%$ average consumer satisfaction level $3.00-3.67$.

\section{b) Importance to Consumer and Sales Point}

Assessment level of consumer interest is done to find out how important the work competence of students according to the donut industry in satisfying the needs of the industry. The assessment was conducted by three donut industries, namely Maple Bakery, PT. Agronesia BMC and Carnation Bakery. The selling point is the contribution of a consumer's need to the selling power of the product (Purwani, 2013). The selling point is determined based on the extent of the influence of the competence if it could be improved the quality of the graduate's selling / competitiveness and the success of the school in the education process. The following table explains the importance to costumer and sales point value of the work competencies required by the donut industry.

TABLE II. IMPORTANCE TO CUSTOMER AND SALES POINT

\begin{tabular}{|c|c|c|}
\hline $\begin{array}{c}\text { Importance to } \\
\text { Costumer }\end{array}$ & Sales Point & Percentage (\%) \\
\hline 4 & 1.5 & 68.08 \\
\hline 3 & 1.2 & 29.79 \\
\hline 2 & 1 & 2.13 \\
\hline
\end{tabular}

\section{c) Improvement ratio}

Ratio improvement or improvement ratio shows the level of improvement that must be done. The result of the calculation of the improvement ratio shows that $8.15 \%$ of the students' work competence in the natural level of improvement is difficult; $60.64 \%$ work competency of student in medium improvement level and $30.85 \%$ student work competence in level of easy repair. 


\section{d) Raw Weight and Normalized Raw Weight}

Raw weight is the value of a competency to determine the priority level of the competence in the education process. Raw weight (RW) is determined multiplying the value of consumer interest rate, SP and IR. The normal weight (normalized raw weight/ NRW) is the percentage of RW which provide in Appendix 15. This appendix shows the RW and NRW work competencies required by the donut industry. In summary, the percentage of RW and NR W raw values is shown in Table 3 .

TABLE III. RAW WEIGHT AND NORMALIZED RAW

\begin{tabular}{|c|c|c|}
\hline Raw Weight & $\begin{array}{c}\text { Normalized Raw } \\
\text { Weight (\%) }\end{array}$ & Percentage (\%) \\
\hline 0.75 & 0.33 & $1.06 \%$ \\
\hline 0.86 & 0.38 & $1.06 \%$ \\
\hline 1.18 & 0.52 & $1.06 \%$ \\
\hline 1.30 & 0.57 & $6.38 \%$ \\
\hline 1.44 & 0.63 & $15.96 \%$ \\
\hline 1.62 & 0.71 & $6.38 \%$ \\
\hline 2.45 & 1.08 & $6.38 \%$ \\
\hline 2.70 & 1.19 & $21.28 \%$ \\
\hline 3.00 & 1.32 & $31.91 \%$ \\
\hline 3.38 & 1.48 & $8.51 \%$ \\
\hline
\end{tabular}

\section{Technical Response Matrix}

This matrix contains about what techniques should be done by UP bakery in order to create work competence in accordance with the needs of the donut industry. The techniques are formed in services improvement which was provided by UP bakery. Technical response is then grouped based on five dimensions of service quality, namely tangible, reliability, response, assurance and empathy.

\section{Relationship Matrix}

This matrix explains how the relationship between industrial needs competence and technical response from UP bakery. The result of determination established by UP Bakery mentor teacher which was showed 23 technical responses able to develop by 94 students work competence according to donut industry requirement. There is $88.3 \%$ work competence needs by donut industry could be developed with the development or improvement of learning quality of productive subjects.

\section{E. Technical Correlation Matrix}

Correlation matrix technique (technical correlation matrix) contains information that is used to determine the relationship between elements of technique. This relationship needs to be known so that the development process of the activity could support each other. Table 4 . This shows the technique with other techniques.

\section{F. Technical Matrix}

\section{1) Relative Contributions and Priorities}

The value of the relative contribution is determined by calculating the normalized raw weight value multiplied by the value of the relationship between the consumer needs and the technical response (relationship). The priority value represents the relative contribution of the technical response to customer satisfaction. Firstly, the highest priority level is occupied by the learning of productive subjects with a relative contribution value of 5.18 and the priority percentage of $26.80 \%$. Furthermore, the second highest priority level is increased supervision with the relative contribution value of 1.42 and the priority percentage of $7.36 \%$. Lastly, the priority third is the standard operating hygiene, sanitation and K3 UP Bakery with a relative value of 1.32 and $6.85 \%$ priority percentage.

TABLE IV. TECHNICAL CORRELATION MATRIX

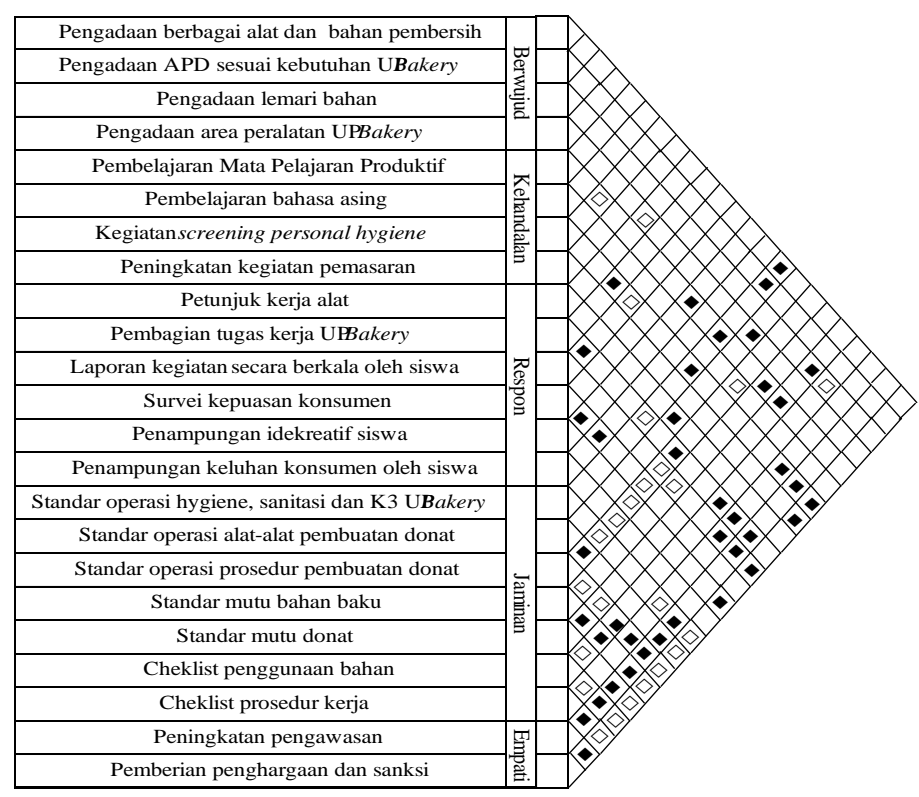

\section{2) Benchmarking}

Benchmarking is done by comparing the performance of UP Bakery process SMK Negeri 2 Cilaku Cianjur with weight (importance level) technical response UP SMK Negeri Cikalongkulon and UP SMK Negeri 1 Bojongpicung. The comparison is done by interviewing the competitor's UP Teacher. Based on the results of the interview with the Teachers of UP / J SMK Negeri Cikalongkulon, it is known that $100 \%$ of the importance of technical response in the category are very important (4). Meanwhile, based on interview with Teachers of UP / J SMK Negeri 1 Bojongpicung, showed that $91,30 \%$ is very essential about level of technical response in category (4) and $8,70 \%$ is important on level of technical response in category (3).

\section{3) The development direction}

The direction of development is determined based on the target value of the technique. The target, which wants to be received, so it is to be determined by the teacher of UP Bakery. The direction of development is obtained from the best value between the value of technical importance of UP Bakery and the importance of the competitor UP. There are $100 \%$ technical response whose development direction should be improved and developed.

\section{4) Lesson learned Productive lesson}

The learning of productive subjects is basically not the main part of the UP. However, the UP is part of the learning 
activities of productive subjects. UP serves as an implementation of learning activities of productive subjects. According Rohanah (2013), UP is a business-based learning program as one of the teaching patterns to provide additional skills of students, in addition to increasing the achievement of the program environment and match with the world of work / industry. Theoretical learning will not be effective if it is not practiced. Similarly practice activities will not be effective if not equipped first with the theory.

\section{5) Improved Supervision}

Controlling is one of the essential things in the implementation of an activity. Supervision could be said well if the activity is in accordance with the standards that have been planned. Teacher of UP bakery and some productive subject teachers of TPHP competency skills do the controlling of UP bakery. Supervision is enforced against several activities, including supervision of the quality of end of donut products which is made every day during the production process because standards of donut product have not been prepared in writing and supervision of the performance of students who are carrying out the activity of UP Bakery. The analysis by using QFD method, which is embodied by HOQ, the priority of UP Bakery technique development, could be done to increase supervision. Improvement of controlling could be done based on the theory that there are three basic types of supervision, namely preliminary supervision, concurrent supervision and feedback monitoring [6].

\section{CONCLUSION}

It is interesting to note that UP bakery has applied $57,14 \%$ stages of method of QFD, in other words has executed four stages from seven stages which must be implemented in applying of QFD method. Furthermore, the learning of productive subjects and improvement of supervision is a priority of technical interest that must be developed by UP bakery in order to develop work competence that suits the needs of the donut industry.

\section{REFERENCES}

[1] Law Number 20 Year 2003 regarding National Education System (UUSPN).

[2] Khoirunnisa, NFF (2016). Application of Quality Function Deployment (QFD) and Kano Method on Conformity Analysis SMK Curriculum Package Expertise of Agricultural Product Processing Technology (TPHP) with Agricultural Industry (Thesis). Faculty of Education Technology and Vocational University of Education Indonesia, Bandung.

[3] Rusnani. (2012). Implementation of Production Units at Public vocational secondary schools Business and Management Group. Journal of Vocational Education, Vol. 2 No. 3. 338 - 354.

[4] Mahfud, T. (2012). Praxis of Entrepreneurship Learning at Catering Production Unit. Journal of Vocational Education, Vol. 2 No. 1. 27 40.

[5] Purwani, DS (2013). Application of Quality Function Deployment Method (QFD) at the Business Unit In SMKN 2 Yogyakarta (Thesis). Faculty of Engineering State University of Yogyakarta, Yogyakarta.

[6] Handoko , H. (2001). Management Edition 2. Yogyakarta: B PFE Yogyakarta. 